\title{
GEO-EYE
}

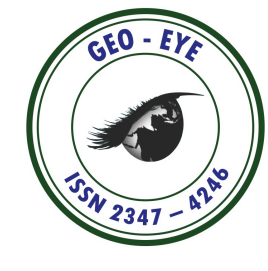

RESEARCH ARTICLE

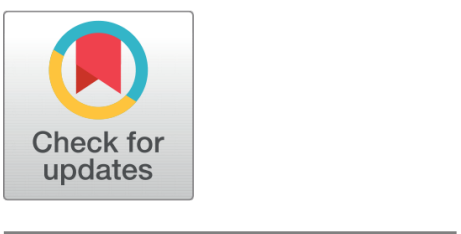

G OPEN ACCESS

Received: 17.03.2020

Accepted: 22.05 .2020

Published: 12.06 .2020

Citation: Mulla IA. (2020). IRRIGATION SYSTEM IN DHARWAD DISTRICT: A GEOGRAPHICAL ANALYSIS. Geo-Eye. 9(1): 33-37. http s://doi.org/10.53989/bu.ge.v9i1.7

Funding: None

Competing Interests: None

Copyright: (c) 2020 Mulla. This is an open access article distributed under the terms of the Creative Commons Attribution License, which permits unrestricted use, distribution, and reproduction in any medium, provided the original author and source are credited.

Published By Bangalore University Bengaluru, Karnataka

ISSN

Print: 2347-4246

Electronic: XXXX-XXXX

\section{IRRIGATION SYSTEM IN DHARWAD DISTRICT: A GEOGRAPHICAL ANALYSIS}

\author{
I A Mulla ${ }^{1}$ \\ 1 Associate Professor, Head Department of Geography, Anjuman Arts, Sci, Com., College \& P.G. \\ Studies, Dharwad, Karnataka, India
}

\section{Abstract}

Irrigation in India has been practiced from ancient times and irrigation tanks and wells are a familiar feature of the India landscape to supplement and conserve the rainfall. Artificial lakes and canals that dot the country in the hundred are centuries old and some of them has served for more than thousand years. Storages and their water courses are common in south, central and eastern India. Hindu monarchs and the Mughal emperors later on, the Britishers undertook a large number of irrigation works.

Water is needed in almost every sphere of human activity. Irrigation through major and medium canal systems was a key component of green revolution that transformed India and made the spectre of famines in India history. Irrigated agriculture is thus responsible for the rapid improvement in the agriculture productivity in the 1960's, 70s, and 80's. There is a marked difference in the levels of contribution from agriculture in the rain-fed and the irrigated areas. In general irrigation is seen to be affecting poverty by increasing returns to the physical, human and social capital; integrating the poor with factor, product and information markets and improving the overall national growth rates.

Among taluks, the area of corps, production and productivity of crops are higher in Dharwad and Navalgund taluks owing to more area under irrigation. Even horticulture crops are also more in these two taluks as compared to other taluks as a consequence of more area under irrigation. The available utilizable water resource of the District, viz: Dharwad, Hubli, Kalghatgi, Kundagol, Navalgund; is considered insufficient to meet all the future needs. Under such a situation, in order to face the challenge of water deficit, apart from accelerating pace of development of available utilizable water resources, all out efforts, on the part of people from every walk of life, would need to be made to conserve every drop of water and improve efficiency in all areas of water use.

Keywords: Irrigation; Sources of Irrigation; Yielding; Cropping; Agriculture Economy

\section{Introduction}

Irrigation is defined as artificially supplying and systematically dividing of water for agriculture and horticulture in order to obtain higher or qualitatively better production. Water is essential to plant growth. Successful farmers have used different methods to apply water to their crops. This artificial addition of water is called irrigation. 
Irrigation is essentially the artificial application of water to overcome deficiencies in rainfall for growing crops. Irrigation is a basic determinant of agriculture because its inadequacies are the most powerful constraints on the increase of agricultural production. In traditional agriculture, irrigation was recognized for its protective role of insurance against the vagaries of rainfall and drought. But now, adoption of high yielding varieties, chemical fertilization and multiple cropping highly used controlled irrigation is quite essential for increasing productivity.

\section{Need for irrigation}

The need for irrigation in Dharwad arises from the following reasons:

- Variability in rainfall: Rainfall in India is very uncertain, which increase the element of risk and makes crop production rather difficult. Normal rainfall is marked by its wide fluctuations in different part as also variation from season to season and year to year in its quantity, incidence and duration. This uncertainly compels irrigation facilities to be provided.

- Unequal distribution of rainfall: In most parts of the district, $80 \%$ of the annual rainfall is received from June to September from the south-west monsoon South kannada And North kannada, where there is a constant deficiency of water.

- To meet crop requirements and soil needs: Different crops require different quantities of water supply throughout their growing provide. For example grain crops require their maximum supply during the time ear heads are formed; while sugarcane, cotton, chillies require more water. Most annual crops do not require water when they are maturing. Besides, sandy soils require frequent water supply than the alluvial or black soil.

- To maximize production: To get high yields and maximum production from land, and to facilitate double and treble cropping, irrigation is a must. According to the I.C.A.R. (Indian Council of Agricultural Research) the production of irrigated crops is on an average 50p.c. to 100p.c. higher than that of the unirrigated crops in the same locality.

- To get efficient use of utilizable flow: Many of the rivers are not perennial and they carry insignificant flows during the rabi season. There is also a wide disparity in the water flow from year to year.

\section{Objectives}

1. To study the impact of irrigation system on the rural farm economy in terms of productivity, cropping pattern and cost of production.
2. To study the impact of irrigation system of Dharwad district on different taluka categories with reference to agriculture.

3. To study the overall impact of irrigation system on auxiliary activities like Yield rate, Cropping, High producing of crops.

\section{Data based Methodology}

The present study selected for Dharwad District for the purpose of enquiry among all the districts of Karnataka State. Since Irrigation is the major source of agricultural development in the district concerned. Of the different categories of sources are selected randomly from the Talukas whose distribution is given and techniques that are developed by geographer and other scientists have been employed. The details of tools and techniques used, maps and graphs have been used for showing water resources and irrigation.

The present study made use of secondary sources of data. The secondary sources of data include reports and records from District Statistical Officer Dharwad.For the purpose of the present study, a year period secondary data covering the period to 2017-18.

\section{Hypotheses}

1. The impact of irrigation system on agriculture economy is positive in terms of agri income and its variability is significantly across the different categories of the sources.

2. The impact of irrigation system is more on the growth of the farm related activities when compared to that of nonfarm related activity. Towards the end of the objectives and hypotheses, the following methodology is adopted.

\section{Study area}

Physical aspects have been considered as basic factors which gives real characteristics of the particular region. Therefore, it is need to understand the physical aspects of the study area to conduct any investigation. Hence, an attempt is made to deal briefly the formation, location and extent, physical features, settlement characteristics, demographic characteristics and economics characteristics. These dimensions have really guiding the researcher to proceed for understand the reality prevailing in a region and helps for planning for further development of a region in different aspects.

\section{Location and Extent}

The study area is located at the fringe zone of Semi - Malnad and Maidan of the north-western parts of the Karnataka State. It has extended between $152^{\prime}$ to $1542^{\prime}$ northern 
latitude and 7443' to75 32‘ eastern longitude having Dharwad, Hubli, Kalaghatgi, Kundgol and Navalgund as the talukas of its junction. There are 367 Revenue Villages and 27 Hamlets, 06 Urban Centers with 05 Municipalities, 127 Gram Panchayat have been distributed on a geographical space in a region. The study region has an area of 4263 square kilometers with population of 1987580 . (2019 census) The density of population is 434 persons per square kilometers (2019 census). The Navalgund taluk (1080 sq. km.) is biggest and Hubli taluka (631sq. km.) is the smallest taluka in terms of area. It is an educational hub in north Karnataka.

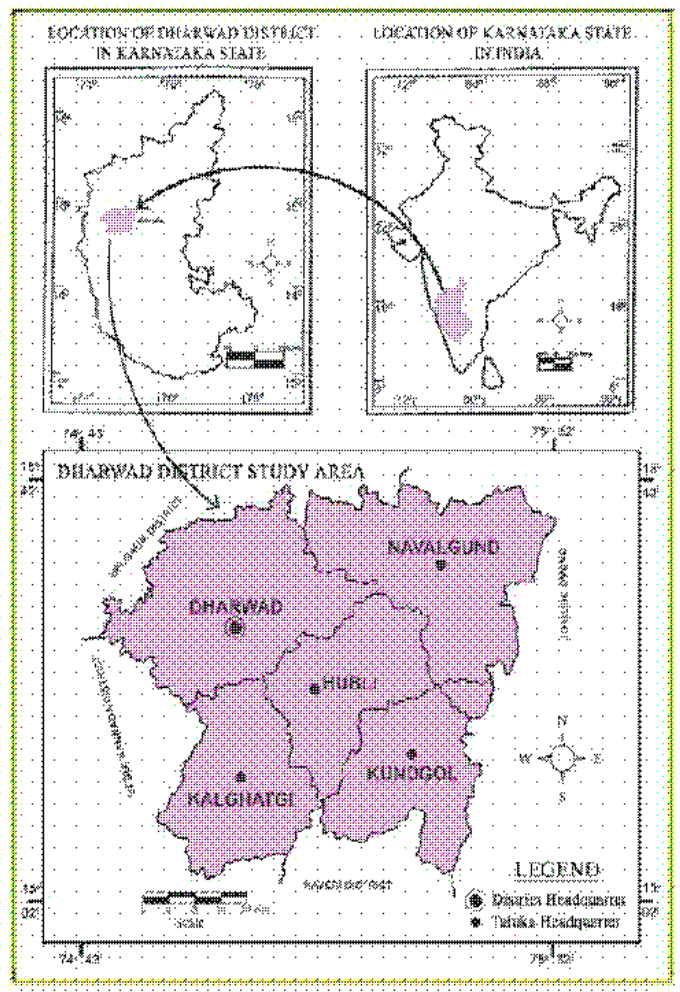

Fig. 1. Location on map

\section{Results and Discussion}

\section{Geographical factors favouring irrigation}

There are certain geographical factor which have led to the development of irrigation in Dharwad district. They are:

- The slope of the plains is so gradual that the canals which are taken out in the upper course of the rivers can easily irrigate the land in the lower valley.

- The soil is fertile which makes the greatest use of irrigation.
- The clay in the sub-soil is deep which acts as reservoir for the rain water which sinks through the porous alluvium of the plains and which is later tapped by wells.

\section{The main sources of irrigation in Dharwad are}

1. Canals 2 Wells (and tube wells 3 Tanks and reservoirs and other sources

\section{Canal Irrigation}

- A canal is an artificial watercourse constructed for water supply and irrigation.

- There are two types of canals:

- Inundation Canals - These are taken out from the rivers without any regulating system like weirs etc at their head. Such canals are useful only during the rainy season.

- Perennial Canals - These are those which are taken off from perennial rivers by constructing a barrage across the river. Most of the canals at present in India are perennial.

- Canals can be an effective source of irrigation in areas of low relief, deep fertile soils, perennial source of water and an extensive command area. Therefore the main concentration of canal irrigation is in Navalgund taluka.

- Merits of canal irrigation: (1) Perennial Source (2) Provides safety from droughts (3) Brings fertile sediments to the fields (4) Economical to serve a large area.

- Demerits: (1) Canal water soaks into the ground and leads to water logging, increases salinization, and leads to marshy conditions leading to malaria and flooding (2) Wastage of water.

\section{Wells (and Tube Wells)}

- A well is a hole dug in the ground to obtain the subsoil water. An ordinary well is about 10-12 meters deep but deeper wells up to 20-30 meters are also dug.

- A tube well is a deeper well (generally over 20-30 meters deep) from which water is lifted with the help of a pumping set operated by an electric motor or a diesel engine.

- Well irrigation is gradually giving way to energized tube wells. But there are many wells still in use where electricity is not available or the farmers are too poor to afford diesel oil.

- This method of irrigation is popular in those areas where sufficient sweet ground water is available.

- At present irrigation from canals and tube wells accounts for more than $60 \%$ of the net irrigated area in the district.

- Dharwad district has the largest area under well irrigation which accounts for $18 \%$ of the well irrigated area of 
the District. Hubli, Dharwad, Kundagol Talukas account for about three-fourths of the total well-irrigated area

- Merits of well irrigation:

- Simplest

- Cheapest

- Well is an independent source of irrigation and can be used as and when the necessity arises. Canal irrigation, on the other hand, is controlled by other agencies and cannot be used at will.

- Some ground water salts are useful for crops

- Does not lead to salinization and flooding problems

- There is a limit to the extent of canal irrigation beyond the tail end of the canal while a well can be dug at any convenient place.

- Demerits:

- Only limited area can be irrigated. Normally, a well can irrigate 1 to 8 hectares of land.

- Not suitable for dry regions.

- Overuse may lead to lowering of water table.

\section{Tank irrigation}

A tank is a reservoir for irrigation, a small lake or pool made by damming the valley of a stream to retain the monsoon rain for later use.

1. It accounts for approximately $4 \%$ of the net irrigated area in Dharwad District.

2. Tank Irrigation is popular in the Hubli and Dharwad areaare the leading districts.

(a) The undulating relief and hard rock's make it difficult to dig canals and wells.

(b) There is little percolation of water due to hard rock structure and ground water is not available in large quantities.

(c) Scattered nature of agricultural fields.

- Merits

- Most of the tanks are natural and do not involve cost for their construction.

- Independent source for an individual farmer or a small group of farmers.

- Longer life span.

- can be used for fishing also.

- Demerits

- Depends on rain and these tanks may dry up during the dry season.

- Silting of their beds.

- Require large areas.

- Evaporation losses.

- Sometimes there might be a need to lift the water to take it to the field.

\section{Net area irrigated under different sources in Dharwad District}

1. High zone canal irrigation: This zone comprises the north eastern taluka like Navalgund which is highly irrigated good development of irritation. Entire taluka has level topography has recorded. It is very good water supply to the taluk and $100 \%$ irrigation system in Navalgund. The total gross irrigated area is 15383 hectors and total net area irrigated is 12774 Hectors.

2. Moderate zone tanks irrigation: This zone comprises the northwestern talukas of Dharwad. the number $\mathrm{f}$ tube wells in this taluka is 1712 tube wells in the year 2017-18. Dharwad taluka's gross irrigation are in talukas has 14599 hectors area.

3. Low zone area - Wells and others: The number of tanks is 371 tanks but this type of irrigation is very popular in the district. Other source if irrigation in the Navalgund taluka's total gross irrigated area is 8605 Hectors.This zone has Hubli, Kaghatagi, Kundagol talukas are very low irrigated.

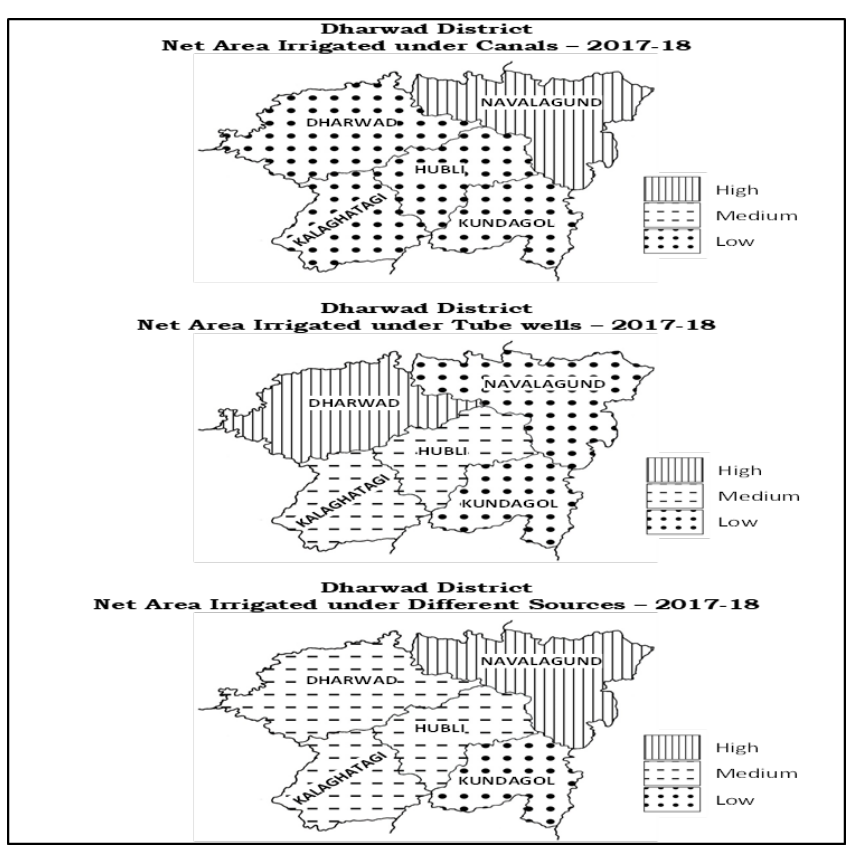

Fig. 2. Net area irrigated under different sources in Dharwad District

\section{Conclusion}

Historical evidences suggest that Dharwad was a popular seat of human habitation even during Paleolithic Age. Dharwad district is a part of Northern transitional zone, having a typical dryland eco-system except parts of Navalgund taluks which have irrigation facilities from Malaprabha 
Table 1. Gross and Net Area Irrigated under Different Sources 2017-18

\begin{tabular}{|c|c|c|c|c|c|c|c|c|c|c|c|c|c|}
\hline \multirow{3}{*}{$\begin{array}{l}\text { Sl. } \\
\text { No. }\end{array}$} & \multirow{3}{*}{ Taluk } & \multicolumn{12}{|c|}{ 2017-18 Net Area Irrigated (in Hectares) } \\
\hline & & \multicolumn{4}{|c|}{ Canals } & \multicolumn{4}{|c|}{ Tanks } & \multicolumn{4}{|l|}{ Wells } \\
\hline & & $\begin{array}{l}\text { Length } \\
\text { in } \\
\text { Kms }\end{array}$ & $\begin{array}{l}\text { Gross } \\
\text { Irri- } \\
\text { gated } \\
\text { Area }\end{array}$ & $\begin{array}{l}\text { Net } \\
\text { Area } \\
\text { Irri- } \\
\text { gated }\end{array}$ & $\begin{array}{l}\text { Percen } \\
\text { tage }\end{array}$ & $\begin{array}{l}\text { Number } \\
\text { of } \\
\text { Tanks }\end{array}$ & $\begin{array}{l}\text { Gross } \\
\text { Irri- } \\
\text { gated } \\
\text { Area }\end{array}$ & $\begin{array}{l}\text { Net } \\
\text { Irri- } \\
\text { gated } \\
\text { Area }\end{array}$ & $\begin{array}{l}\text { Percen } \\
\text { tage }\end{array}$ & $\begin{array}{l}\text { Number } \\
\text { of } \\
\text { Wells }\end{array}$ & $\begin{array}{l}\text { Gross } \\
\text { Irri- } \\
\text { gated } \\
\text { Area }\end{array}$ & $\begin{array}{l}\text { Net } \\
\text { Irri- } \\
\text { gated } \\
\text { Area }\end{array}$ & $\begin{array}{l}\text { Percen } \\
\text { tage }\end{array}$ \\
\hline 1 & Dharwad & 0 & 0 & 0 & 0 & 371 & 0 & 0 & 0 & 406 & 0 & 0 & 0 \\
\hline 2 & Hubli & 8 & 0 & 0 & 0 & 64 & 0 & 0 & 0 & 422 & 0 & 0 & 0 \\
\hline 3 & Kalaghatagi & 0 & 0 & 0 & 0 & 782 & 0 & 0 & 0 & 89 & 0 & 0 & 0 \\
\hline 4 & Kundagol & 0 & 0 & 0 & 0 & 14 & 0 & 0 & 0 & 106 & 0 & 0 & 0 \\
\hline \multirow[t]{2}{*}{5} & Navalagund & 78 & 15383 & 12774 & 100.00 & 14 & 0 & 0 & 0 & 89 & 0 & 0 & 0 \\
\hline & $\begin{array}{l}\text { District } \\
\text { Total }\end{array}$ & 86 & 15383 & 12774 & 100.00 & 1245 & $\mathbf{0}$ & $\mathbf{0}$ & $\mathbf{0}$ & 1112 & $\mathbf{0}$ & $\mathbf{0}$ & $\mathbf{0}$ \\
\hline
\end{tabular}

Sources: Dharwad District a Glance

Table 2. Gross and Net Area Irrigated under Different Sources 2017-18

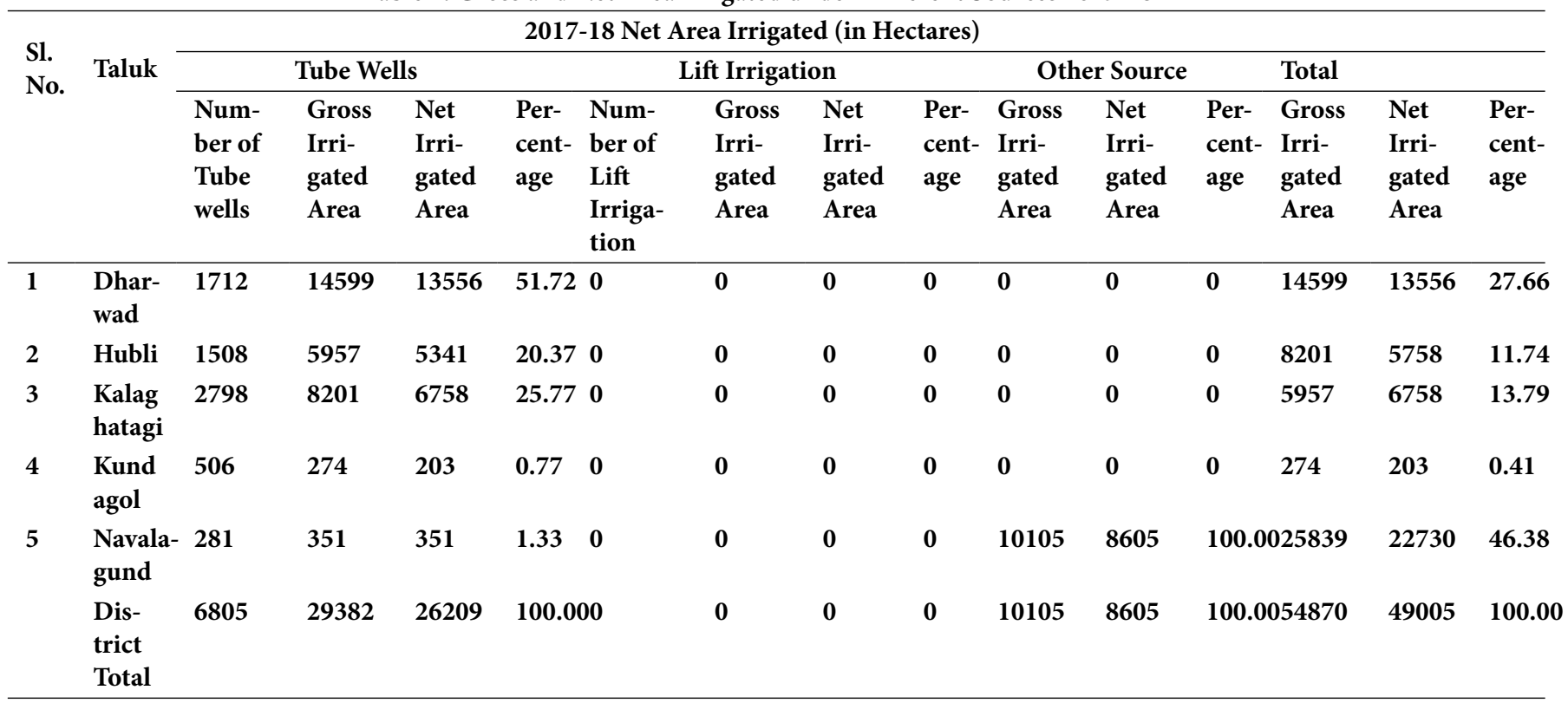

Sources: Dharwad District a Glance

Canal. Erratic monsoon and frequent dry spells elevates the risk in farming. The soil and water conservation measures through watershed approach, drought proofing is absolutely necessary to ensure reasonable level of crop yields. The whole district represents un-uniform rainfall pattern. Under AIBP (Accelerated Irrigation Benefit Programme), various activities are proposed by major irrigation, minor irrigation departments wherein incomplete works are proposed to be taken up in different taluks at an estimated cost of Rs. 23688.89 crores and this would create irrigation potential of 49673 ha in the district.

\section{References}

1) Ahmad A, Siddiqui MF. Crop Association Patterns in the Luni Basin. Geographer. 1967;p. 69-80.

2) Bansil PC. Agricultural Problems of India. New Delhi. Vikas Publication. 1977.

3) Bhatia SS. A New Measure of Agricultural Efficiency in Uttar Pradesh, India. Economic Geography. 1967;43(3):244-260. Available from: https: //dx.doi.org/10.2307/143292.

4) Husain M. Terms and Concepts of Geography. New Delhi, McGraw Hill Education. 2016.

5) Shafi M. Agricultural Geography. 2006.

6) Singh J. An Agricultural Atlas of India. 1974.

7) Singh J, Dhillon SS. Aagricultural Geography. New Delhi. Tata McGrawHill. 1984.

8) Symon L. Agricultural Geography. 1966. 